\title{
PEMANFAATAN FACEBOOK MARKETING UNTUK MENINGKATKAN OMSET PENJUALAN UMKM TEMBILAHAN
}

\author{
Dwi Yuli Prasetyo ${ }^{1}$, Fitri Yunita2, Abdul Muni ${ }^{3}$ \\ $1,2,3$ Prodi Sistem Informasi, Fakultas Teknik dan Ilmu Komputer, Universitas Islam Indragiri \\ Email: dwiyuliprasetyo@gmail.com¹ (korespondensi) fitriyun@gmail.com², abdulmuni@live.com³
}

\begin{abstract}
At present, the marketing and sales of UMKM products in Tembilahan are still done by manually or through broadcast messages and waiting for visitors to come to the store. This method is not optimal in delivering information because the promotion does not reach people who are far from the location of the store. Today's social media is a very popular tool and is in demand by UMKM players, one of which is Facebook in which there is a marketplace feature that can reach promotions and sales that do not know space and time. This study aims to find out and analyze the Facebook marketing communication strategy used by Gadisty Screen Printing Tembilahan includes planning and the results of its implementation in increasing sales in each branch. The method used is observation, in-depth interviews and documentation. Research was carried out in Tembilahan, data was analyzed using Miles \& Huberman models. The results showed Facebook accommodated the components that existed in marketing communication strategies such as providing consumer data to validate segmentation, targeting, and positioning as well as research material in determining the production of Facebook marketing content. Marketing strategies are executed on Facebook FanPage, Personal and Group accounts. The three main components of Facebook marketing running marketing mixes such as advertising, sales promotions, private sales, direct marketing, public relations and publicity. Popular marketing content on Facebook is the characteristics of Cover / Soft Selling and Video..
\end{abstract}

Keywords: Facebook Marketing, Tembilahan, Communication Strategy, Online Marketing

\begin{abstract}
Abstrak
Saat ini pemasaran dan penjualan hasil produk UMKM di tembilahan masih dilakukan dengan cara manual atau melalui broadcast pesan dan menunggu pengunjung datang ke toko. Metode ini belum optimal dalam penyampaian informasi karena promosi yang dilakukan tidak menjangkau masyarakat yang berada jauh dari lokasi toko. Media sosial saat ini menjadi alat yang sangat populer dan diminati oleh pelaku UMKM salah satunya adalah facebook yang di dalamnya terdapat fitur marketplace yang dapat menjangkau promosi dan penjualan yang tidak mengenal ruang dan waktu. Penelitian ini bertujuan mengetahui dan menganalisis strategi komunikasi pemasaran facebook yang digunakan oleh Gadisty Sablon Tembilahan meliputi perencanaan dan hasil pelaksanaannya dalam meningkatkan penjualan di setiap cabang. Metode yang digunakan yaitu observasi, wawancara mendalam dan dokumentasi. Penelitian dilaksanakan di tembilahan, Data dianalisis dengan menggunakan model Miles \& Huberman. Hasil penelitian menunjukkan facebook mengakomodasi komponen yang ada pada strategi komunikasi pemasaran seperti menyediakan data-data konsumen untuk memvalidasi segmentasi, targeting, dan positioning sekaligus menjadi bahan riset dalam menentukan produksi konten facebook marketing. Strategi marketing di eksekusi pada akun facebook fanpage, personal dan grup. Tiga komponen utama facebook marketing tersebut menjalankan bauran pemasaran seperti periklanan, promosi penjualan, penjualan secara pribadi, pemasaran langsung, hubungan masyarakat dan publisitas. Konten marketing populer pada facebook ialah dengan ciri cover/soft selling dan video.
\end{abstract}

Kata kunci: facebook marketing, tembilahan, strategi komunikasi, pemasaran online

\section{PENDAhuluaN}

Seiring dengan kemajuan perkembangan zaman dan teknologi ditambah lagi dengan kondisi pandemi yang terjadi pada saat ini 
yang diakibatkan oleh penyebaran virus covid-19. Dimana virus ini melanda Indonesia bahkan dunia. Seorang wirausaha atau yang saat ini lebih dikenal dengan istilah entrepreneur adalah seseorang yang bisa membawa perubahan, inovasi dan ideide baru. Penerapan inovasi pada industri tidak selalu melalui proses yang rumit, riset yang banyak, dan penggunaan sumber daya yang besar. Inovasi bisa dilakukan dengan sedikit modifikasi namun dapat memberikan dampak yang besar. Sebuah unit usaha tidak bisa mengandalkan satu aspek saja, tetapi bagaimana mengelola paradoks antara satu hal dan lainnya. Diera teknologi sekarang ini, model bisnis baru muncul sebagai inovasi dari pemasaran konvensional bergeser ke pemasaran modern menggunakan media digital. Proses jual beli konvensional yang mengharuskan penjual dan pembeli harus bertatap muka kini mampu dimediasi oleh media digital sehingga menghasilkan tren pemasaran baru. Munculnya online shop, grup dagang online, platform e-commerce, dan model ebusiness lainnya adalah bukti bahwa masyarakat saat ini menginginkan kemudahan dalam upaya mendapatkan apa yang diinginkan. Apalagi Indonesia memiliki potensi pasar besar. Pemanfaatan aktivitas ekonominya digunakan untuk mengecek harga, membeli dan menjual barang. Dengan kondisi yang terjadi pada dunia saat ini. Tentu saja sangat tepat untuk para pelaku bisnis untuk berbisnis secara online didalam media social akan lebih efektif dan efisiaen atau yang sering kita dengar dengan sebutan ecommerce [1].

Usaha kecil dan menengah (UKM) merupakan salah satu bagian terpenting dalam perekonomian kerakyatan di suatu wilayah maupun suatu negara. Usaha kecil dan menengah sangat berperan dalam perekonomian Indonesia, sebagai contoh usaha kecil dan menengah sangat berperan penting pada saat terjadinya krisis moneter tahun 1998 dan dipandang sebagai suatu penyelamat dalam proses perekonomian Indonesia, mendorong laju pertumbuhan ekonomi maupun penyerapan tenaga kerja [2].

Jenis UMKM yang tergabung dalam komunitas ini mempunyai latar belakang yang berbeda-beda, seperti UMKM yang bergerak dalam bidang makanan (Food), Fashion, dan kerajinan (Craft). Dengan berbagai jenis latar belakang ini menjadi peluangan untuk meningkatkan potensi ekonomi masyarakat. Mengingat masingmasing UMKM mempunyai keunikan dan kekhasan masing-masing. Dalam keberlangsungan kegiatan UMKM tersebut, terdapat persoalan bagi beberapa UMKM yaitu dalam hal bagaimana cara mengemas dan menampilkan produk yang mereka miliki sehingga terlihat lebih menarik serta bagaimana memasarkan produk tersebut dengan cara yang efektif serta tepat sasaran khususnya menggunakan media sosial facebook. UMKM harus mulai terlibat dalam sebuah cara baru dan tidak terus melakukan pemasaran dengan dengan cara-cara konvensional, yaitu dengan cara terlibat dalam memanfaatkan teknologi yang saat ini sudah sangat banyak berkembang [3].

Pelaku Usaha Mikro Kecil dan Menengah di Provinsi Riau dari waktu ke waktu terus meningkat disebabkan makin tumbuhnya kesadaran menjadi wirausaha akibat belum seimbangnya jumlah pencari kerja dan lapangan kerja yang tersedia. Jumlah Usaha Mikro Kecil dan Menengah (UMKM) seKabupaten Indragiri Hilir (INHIL) yang terdaftar resmi di Dinas Koperasi (Diskop) dan UMKM Inhil mencapai 8.378 usaha. Berdasarkan data terakhir per-september 2015, secara keseluruhan se-Inhil ada 8.378 UMKM, "kata Kepala Diskop dan UMKM Kabupaten Inhil R. Rida Indaryanti melalui Kabid UMKM, Sumiati kepada awak media, kemarin. Dari total jumlah tersebut, dapat dibagi perkecamatan [4].

\section{TINJAUAN PUSTAKA \\ 2.1. Fecebook Marketing}

Setelah Search Engine Optimization (SEO) sudah dianggap tidak cukup untuk melakukan efektifitas pemasaran di internet, maka lahirlah Web 2.0 atau yang lebih dikenal dengan social media. Diantara sosial media yang populer adalah Facebook, Youtube, Flickr, Twitter, dll. Dari sinilah muncul istilah SMO (Social Media Optimization) yang merupakan teknik baru dalam marketing online, namun bukan berarti teknik lama (SEO) tidak berlaku lagi. Menggabungkan teknik SEO dan SMO untuk aktivitas marketing secara online akan memberi hasil yang luar biasa. Facebook didirikan pada 4 Pebruari 2004, telah mencatatkan lebih dari 37 juta pengguna serta ribuan jaringan bisnis. Facebook telah mengembangkan berbagai ragam aplikasi yang dapat diinstall para pengguna. Aplikasiaplikasi inilah yang memberikan nilai tambah bagi Facebook. Aplikasi yang dikembangkan banyak yang mendukung bisnis dan pekerjaan seperti menjual atau membeli barang. Menjamurnya jejaring sosial seperti Facebook ini membuka peluang yang sangat baik bagi siapa saja 
untuk melakukan aktivitas marketing dengan lebih baik dan berbiaya relatif murah. Aktivitas marketing dan proses bisnis lainnya dengan menggunakan jejaring sosial Facebook dapat disebut juga sebagai E-Commerce. Facebook marketing adalah melakukan aktivitas marketing menggunakan semua fasilitas yang disediakan oleh facebook dengan tujuan meningkatkan penjualan (sales) dan menjalin komunikasi yang lebih langgeng dengan pelanggan (customer relationship). Konsep Facebook Marketing dapat digambarkan pada Gambar 1 [1]

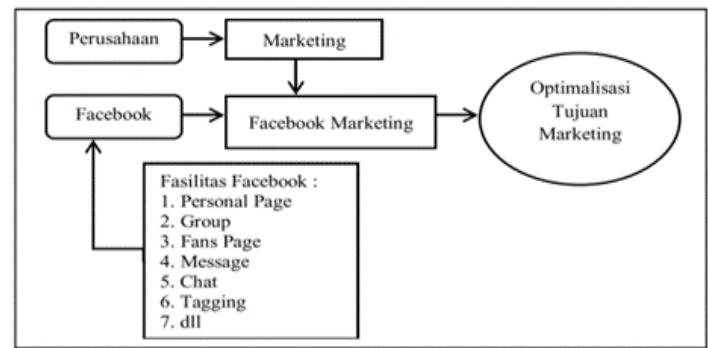

Gambar 1. Konsep Facebook Marketing

\section{2. e-Marketing}

Menurut Strauss dan Frost dalam jurnal [5], tujuh tahap dalam perancangan emarketing adalah Situation Analysis (Analisis Situasi), E-Marketing Strategic Planning (Strategi Perencanaan E-Marketing), Objectives (Tujuan), E-Marketing Strategy (Strategi E-Marketing), Implementation Plan (Rencana Pelaksanaan), Budget (Anggaran), Evaluation Plan (Rencana Evaluasi). Adapun detil penjelasannya adalah :

a. Situation Analysis (Analisis Situasi) Tahap pertama merupakan awal dari konsep bisnis dengan melakukan analisis kekuatan, peluang, kelemahan serta ancaman bagi perusahaan. Dalam bagian ini, analisis situasi yang digunakan adalah analisis SWOT. Menurut Rangkuti (2004), analisis SWOT adalah indentifikasi berbagai faktor secara sistematis untuk merumuskan strategi perusahaan. Analisis ini disarankan pada logika yang dapat memaksimalkan Kekuatan (Strengths) dan Peluang (Opportunities), namun secara bersamaan dapat meminimalkan Kelemahan (Weaknesses) dan Ancaman (Threats). Proses pengambilan keputusan strategi selalu berkaitan dengan pengembangan misi, tujuan, strategi, dan kebijakan perusahaan. Dengan demikian perencanaan strategi (strategic planner) harus menganalisis faktor-faktor strategi perusahaan (kekuatan, kelemahan, peluang, dan ancaman) dalam kondisi yang ada saat ini. Hal ini disebut Analisis Situasi. Analisis SWOT membandingkan antara faktor internal Kekuatan (Strengths) dan Kelemahan (Weaknesses) dengan faktor eksternal Peluang (Opportunities) dan Ancaman (Threats) yang dihadapi dunia bisnis.

b. E-marketing Strategic Planning (Strategi Perencanaan E-marketing) Dalam tahap ini terdapat metodologi tujuh langkah sederhana yang membantu dalam mengevaluasi dan menganalisis peluang pasar (Market Opportunity Analysis/MOA), yaitu: Mengidentifikasi kebutuhan pelanggan yang belum terpenuhi mengidentifikasi pelanggan tertentu yang akan dituju oleh perusahaan. Menilai keuntungan yang berkaitan dengan kompetisi menilai sumber daya perusahaan untuk memberikan penawaran menilai kesiapan pasar akan teknologi. Menentukan peluang secara konkret. Menilai peluang daya tarik bagi pelanggan. Strategi perencanaan e-marketing meliputi segmentation, targeting, differentiation, dan positioning

c. Objectives (Tujuan) Tujuan dalam emarketing mencakup aspek tugas, kuantitas, dan waktu. Tugas (apa yang akan dicapai). Kuantitas yang terukur (seberapa banyak). Time frame (kapan). Sebagian besar e-marketing bertujuan untuk mencapai berbagai tujuan seperti berikut: Meningkatkan pangsa pasar. Meningkatkan jumlah komentar pada sebuah blog atau website. Meningkatkan pendapatan penjualan. Mengurangi biaya (misalnya biaya distribusi atau promosi). Mencapai tujuan merek (seperti meningkatkan kesadaran merek). Meningkatkan ukuran database. Mencapai tujuan Customer Relationship Management (CRM)(seperti meningkatkan kepuasan pelanggan, frekuensi pembelian, atau tingkat referensi pelanggan). Memperbaiki manajemen rantai suplai (seperti dengan meningkatkan koordinasi anggota, menambahkan mitra, atau mengoptimalkan tingkat persediaan).

d. E-marketing Strategy (Strategi Emarketing) Strategi e-marketing mencakup strategi mengenai 4P dan hubungan manajemen (relationship management) untuk mencapai tujuan rencana mengenai Product (Produk), Price (Harga), Place (Saluran Distribusi), dan Promotion (Promosi).

e. Implementation Plan (Rencana 
Pelaksanaan) Pada tahap ini perusahaan memutuskan bagaimana untuk mencapai tujuan melalui strategi yang efektif dan kreatif. Pemasar memilih bauran pemasaran (4P), strategi manajemen dan strategi lain untuk mencapai tujuan rencana dan kemudian menyusun rencana pelaksanaan (Implementation Plan). Perusahaan juga memeriksa untuk memastikan organisasi pemasaran yang tepat di tempat pelaksanaan (staf, struktur departemen, penyedia layanan aplikasi, dan lain-lain di luar perusahaan). Internet telah mengubah tempat pertukaran dari marketplace marketplace (seperti, interaksi face-toface) menjadi marketspace (seperti, interaksi screen-to-face). Perbedaan utama adalah bahwa sifat hubungan pertukaran sekarang ditengahi oleh interface teknologi. Dengan perpindahan dari hubungan antar muka peoplemediated menjadi technology-mediated, terdapat sejumlah pertimbangan perancangan interface yang dihadapi. Menurut Rayport dan J.Jaworski. (2003), ada berbagai elemen dalam mendesain sebuah situs web, yaitu context (konteks dari situs mencerminkan nilai keindahan dan kegunaan dari situs tersebut), content (konten merupakan semua objek digital yang terdapat dalam sebuah web baik dalam bentuk audio, video, image ataupun text), community (komunitas merupakan ikatan hubungan yang terjadi antara sesame pengunjung atau pelanggan dari sebuah website karena adanya kesamaan minat atau hobi), customization (kustomisasi merupakan kemampuan situs untuk memodifikasi dirinya sesuai dengan keinginan penggunanya), communication (komunikasi antara perusahaan dengan pelanggan, terdiri dari Broadcast Dimension, Interactive Dimension, dan Hybrid Dimension), connection (kemampuan sebuah website untuk berpindah dari sebuah webpage ke webpage lainnya ataupun website lainnya dengan onclick baik pada text, images maupun toolbars yang lain), dan commerce (commerce merupakan fitur dari customer interface yang mendukung berbagai aspek dari transaksi perdagangan dan memiliki dimensi seperti registration, shopping cart, security, credit card approval, one click shopping, order through affiliates, configuration technology, order tracking, delivery option).

f. Budget (Anggaran) Kunci dari perencanaan strategis adalah untuk mengidentifikasi hasil yang diharapkan dari suatu investasi. Selama pelaksanaan rencana, pemasar akan terus memantau pendapatan aktual dan biaya untuk melihat hasil yang telah dicapai. Internet merupakan salah satu tools yang dapat digunakan untuk memantau hasil karena catatan teknologi pengunjung setiap klik. Untuk mendapatkan informasi anggaran yang dapat dipertanggungjawabkan, perlu dibuat perhitungan tentang revenue forecast (perkiraan pendapatan), intangible benefits (manfaat tidak berwujud), cost savings (penghematan biaya), dan e-marketing costs (biaya emarketing).

g. Evaluation Plan (Rencana Evaluasi) Perencanaan e-marketing dilaksanakan, keberhasilannya tergantung pada evaluasi yang terus-menerus. Jenis evaluasi ini tergantung pada tujuan rencana. Untuk menentukan hasil pemasarannya, perusahaan dapat menggunakan balanced scorecard untuk mengukur kesuksesan dari program internet marketing dan apakah program internet marketing tersebut cocok sesuai dengan objektif dari perusahaan.

\subsection{Penjualan}

Penjualan dalam jurnal [6] merupakan kegiatan yang dilakukan oleh penjual dalam menjual barang atau jasa dengan harapan akan memperoleh laba dari adanya transaksi-transaksi tersebut dan penjualan dapat diartikan sebagai pengalihan atau pemindahan hak kepemilikan atas barang atau jasa dari pihak penjual ke pembeli. Penjualan adalah pendapatan lazim dalam perusahaan dan merupakan jumlah kotor yang dibebankan kepada pelanggan atas barang dan jasa. Dapat disimpulkan penjualan adalah pemindahan hak kepemilikan atas barang atau jasa yang yang dilakukan perusahaan sebagai usaha pokok. Ada beberapa teori yang disampaikan yaitu :

a. Strategi penjualan Periklanan, semua bentuk penyajian non personal promosi ide-ide barang produk atau jasa yang dilakukan oleh sponsor tertentu yang dibayar.

b. Promosi penjualan, insentif jangka pendek untuk merangsang pembeli atau penjualan suatu produk.

c. Publisitas, suatu stimulasi non personal terhadap permintaan suatu produk, jasa atau unit dagang dengan penyebaran kebutuhan akan produk- produk tertentu disuatu media yang disebarluaskan atau 
menghasilkan suatu sosok kehadiran yang menarik mengenai produk di radio, ditelivisi atau panggung yang tidak dibayar oleh sponsor.

d. Penjualan pribadi, penyajian lisan dalam suatu pembicaraan dengan suatu atau beberapa pembeli potensial dengan tujuan untuk melakukan penjualan.

e. Pemasaran langsung, penggunaan surat, telepon penghubung non personal lainnya untuk berkomunikasi dengan atau mendapatkan respon dari pelanggan dan calon pelanggan tertentu.

\subsection{UMKM}

Usaha Kecil Menengah atau sering disingkat dengan UMKM adalah salah satu bagian penting dari perekonomian suatu negara maupun daerah, begitu juga dengan negara Indonesia. Usaha Kecil Menengah merupakan kegiatan ekonomi rakyat yang berskala kecil dan menengah serta perlu dilindungi untuk mencegah dari persaingan usaha yang tidak sehat. UMKM di Indonesia memberikan kontribusi yang sangat signifikan terutama ketika krisis yang dialami pada periode 1998 sampai dengan periode 2000. UMKM di Indonesia telah dapat perhatian dan pembinaan dari pemerintah dengan membuat portofolio kementrian yaitu Menteri Koperasi dan UMKM. Terdapat tiga bidang yang dapat dijelaskan sebagai berikut:

a. Perusahaan jasa, yaitu perusahaan yang produknya adalah bersifat non fisik yang dimana kegiatannya menyediakan jasa untuk pelanggan.

b. Perusahaan dagang, yaitu perusahaan yang membeli barang dari perusahaan lain dan menjualnya kepada pihak yang membutuhkan konsumen.

c. Perusahaan manufaktur, yaitu perusahaan yang membeli bahan baku, kemudian mengolahnya hingga menjadi produk jad yang siap dijual dan dipakai.

Menurut UU No. 20 Tahun 2008, pengertian Usaha Mikro Kecil Menengah maupun usaha besar yaitu : Usaha Mikro merupakan usaha produktif milik orang perorangan dan / atau badan usaha perorangan yang memenuhi kriteria Usaha Mikro sebagaimana diatur dalam Undang Undang ini [7].

\subsection{Kabupaten Indragiri Hilir}

Kabupaten Indragiri Hilir resmi menjadi Daerah Tingkat II berdasarkan Undangundang No.06 Tahun 1965 tanggal 14 Juni 1965 (LN RI No.49). Kabupaten Indragiri Hilir terletak di pantai Timur pulau Sumatera, merupakan gerbang selatan
Propinsi Riau, dengan luas daratan $11.605,97 \mathrm{~km}^{2}$ dan peraiaran $7.207 \mathrm{Km}^{2}$ berpenduduk kurang lebih 759.793 jiwa yang terdiri dari berbagai etnis, Indragiri Hilir yang sebelumnya dijuluki "Negeri Seribu Parit" yang sekarang terkenal dengan julukan "NEGERI SERIBU JEMBATAN" dikelilingi perairan berupa sungai-sungai besar dan kecil, parit, rawa-rawa dan laut, secara fisiografis Kabupaten Indragiri Hilir beriklim tropis merupakan sebuah daerah dataran rendah yang terletak diketinggian 04 meter di atas permukaan laut dan dipengaruhi oleh pasang surut.

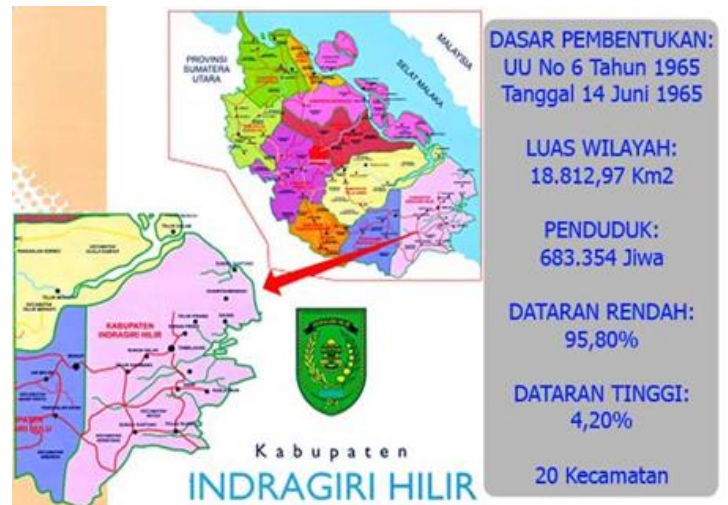

Gambar 2. Peta Kab. Indragiri Hilir Sumber : inhilkab.go.id (2016)

Gambar 1. Peta Kab. Indragiri Hilir yang sebagian besar dari luas wilayah atau 93,31\% daerah Kabupaten Indragiri Hilir merupakan daerah dataran rendah, yaitu daerah endapan sungai, daerah rawa dengan tanah gambut (peat), daerah hutan payau (mangrove) dan terdiri atas pulaupulau besar dan kecil dengan luas lebih kurang 1.082.953,06 hektar dengan ratarata ketinggian lebih kurang 0-3 Meter dari permukaan laut.Sedangkan sebagian kecilnya $6,69 \%$ berupa daerah berbukitbukit dengan ketinggian rata-rata 6-35 meter dari permukaan laut yang terdapat dibagian selatan Sungai Reteh Kecamatan Keritang, yang berbatasan dengan Propinsi Jambi. Dengan ketinggian tersebut, maka pada umumnya daerah ini dipengaruhi oleh pasang surut, apalagi bila diperhatikan fisiografinya dimana tanah-tanah tersebut terbelah-belah oleh beberapa sungai, terusan, sehingga membentuk gugusan pulau-pulau. Kabupaten Indragiri Hilir menyimpan potensi besar dalam berbagai sektor Perekonomian, terutama dibidang Perkebunan, Perikanan/kelautan dan Perindustrian dimana sampai saat ini belum tergarap secara maksimal. Disektor perkebunan, beberapa komoditi unggulan adalah kelapa lokal, kelapa hibrida, kelapa 
sawit dan sagu.Kabupaten Indragiri Hilir terbagi 20 Kecamatan, 174 Desa dan 18 Kelurahan. Kota Tembilahan yang terletak di Kecamatan Tembilahan merupakan Ibukota Kabupaten Indragiri Hilir dibangun di atas tanah berawa yang dialiri Sungai Indragiri merupakan urat nadi jalur perhubungan air. Kuala Enok merupakan kota pelabuhan yang berpotensial menjadi sentra industri kelapa, yang dahulunya hanya ditempuh menggunakan transportasi air sekarang telah dapat ditempuh melalui jalur darat karena telah dibukanya jalan darat sebagi akses menuju pelabuhan samudera. Sungai Guntung di Kecamatan Kateman adalah tempat lainnya yang menarik untuk dijadikan sentra perdagangan dan industri.

Terdapat empat pelabuhan laut dan sungai yang berorientasi Ekspor-Impor yaitu Pelabuhan : Kuala Enok, Kuala Gaung, Sungai Guntung dan Palabuhan Parit 21 Tembilahan. Dari bagian selatan daerah ini, jarak ke Batam dan Singapura bisa ditempuh dalam waktu 2,5 jam dengan menggunakan Speed Boat. Untuk lalu lintas Ekspor-Impor tersedia kapal-kapal Lintas Negara dengan tujuan pelayaran keberbagai Pelabuhan penting di dunia, khususnya Asia dan Eropa.Kabupaten Indragiri Hilir juga memiliki Bandar Udara, yaitu Bandara Tempuling yang telah diuji coba dan telah dioperasikan melayani keberangkatan jemaah haji menuju Batam. Nantinya Bandara Tempuling dioperasikan melayani rute penerbangan regional sehingga membuat daerah ini makin mudah diakses sebagai pintu Gerbang Riau menuju kancah Ekonomi Global.

Sebagai sebuah daerah yang kaya akan sumberdaya alam, dan menyimpan berbagai potensi ekonomi, Kabupaten Indragiri Hilir menjanjikan banyak kemungkinan dimasa depan. Didukung letak geografis yang strategis, serta ditunjang tersedianya berbagai infrastruktur dan kebijakan Pemerintah dalam pembangunan, daerah ini merupakan daerah investasi yang layak diperhitungkan dalam era ekonomi global.Untuk menunjang percepatan pertumbuhan ekonomi dan mempermudah investasi, Pemerintah Daerah telah membangun berbagai infrastruktur, terutama yang berkaitan dengan sarana dan prasarana transportasi untuk mempermudah akses dari dan keluar Kabupaten Indragiri Hilir, baik melalui jalur darat, laut maupun udara, serta menciptakan iklim investasi yang kondusif yang mempermudah sektor swasta untuk menjadi pelaku bisnis di daerah ini [8].

\section{METOdOLOGI PENELITIAN}

Penelitian ini dilaksanakan di Gadisty Sablon Tembilahan. Lokasi tepatnya di jalan telaga biru parit 9 tembilahan. Penelitian dengan pendekatan kualitatif menekankan analisis proses dari proses berpikir secara induktif yang berkaitan dengan dinamika hubungan antar fenomena yang diamati, dan senantiasa menggunakan logika ilmiah. Pemilihan informan dalam penelitian ini menggunakan teknik purposive sampling, yakni dipilih berdasarkan kriteria yang sudah ditentukan sesuai dengan tujuan penelitian. Dalam penelitian ini pemilihan informan adalah pihak yang representatif dalam memberikan informasi terkait penelitian penulis mengenai facebook marketing Gadisty Sablon Tembilahan, diantaranya: marketing online, desainer grafis, manajer, pendiri /pemilik bisnis, konsumen (pengguna facebook), pengamat/praktisi sosial media marketing. Teknik pengumpulan data yang digunalan adalah wawancara (in depth interview), observasi dan dokumentasi. Analisis data dilakukan dengan metode deskriptif kualitatif, dengan menjelaskan fenomena-fenomena yang terjadi di lapangan. Analisis data menggunakan model Miles dan Huberman. Teknik analisis data model interaktif Miles \& Huberman terdiri dari empat tahapan pengumpulan data, Reduksi data, Display data, Penarikan kesimpulan atau Verifikasi.

\section{HASIL DAN PEMBAHASAN}

\subsection{Periklanan (Advertising)}

Promosi ide dan barang menggunakan metode facebook grup yang diatur menggunakan facebook. Admin membuat skema kampanye kiriman tertentu yang diunggah melalui fanpage. Memasarkan produk difacebook sangatlah mudah hanya perlu masuk kegroup jual beli facebook seperti fjb tembilahan kemudian memposting barang yang akan dipasarkan serta mencantumkan nomor hp agar pelanggan lebih mudah untuk berkomunikasi dengan pelanggan.

\subsection{Promosi penjualan Promotion)}

Untuk mendorong keinginan konsumen dalam membeli baju di Gadisty Sablon Tembilahan. Koordinasi antara pemilik bisnis, manajer marketing, admin dan pembuat konten dalam membuat kampanye promosi. Seperti yang dicontohkan oleh admin dalam membuat promosi produk seperti pemberian diskon, voucher belanja dari pemenang kuis dan lainnya terlihat pada Gambar 3 


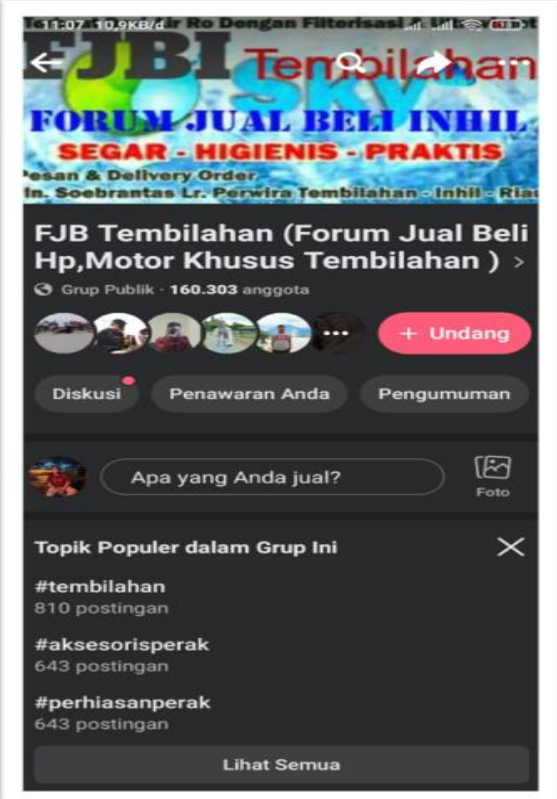

Gambar 3. FJB Gadisty Sablon Tembilahan

\subsection{Hubungan Publisitas Publicity)}

Informan penelitian baik admin pengamat, dan manajer marketing sendir sepakat bahwa facebook tidak sekedar fokus pada iklan saja. Namun bagaimana cara mendapatkan engagement dalam interaksi. Membuat publik mengetahui, berinteraksi, tertarik dan memberikan respon positif terhadap produk akan berdampak pada penjualan. Gadisty Sablon Tembilahan memfokuskan akun personal sebagai akun yang bertindak dalam menjaga relasi baik dengan konsumen atau membangun loyalitas. Selain itu dikenal pula istilah soft selling dimana admin tidak secara gamblang beriklan namun lebih kepada membagikan cerita atau pesan dengan kemasan interaktif namun tetap dengan tujuan utama berjualan secara tidak langsung. Terdapat pula tanggapan informan selaku konsumen yang mengaku bahwa komunikasi yang dibangun oleh admin direspon dengan tanggap. Hal ini juga dicantumkan oleh facebook yang menyebutkan bahwa admin responsif dalam merespon pertanyaan yang masuk dalam kolom komentar ataupun pesan pribadi. Adapun tanggung jawab dari pihak produsen jika terdapat hal yang tidak menyenangkan bagi konsumen Gadisty Sablon Tembilahan, tim marketing dan owner berdiskusi untuk klarifikasi, meminta maaf dan memberikan voucher belanja. Hal ini dinilai oleh konsumen sebagai bentuk tanggung jawab yang baik dan diselesaikan menggunakan komunikasi facebook. Hal ini pula membuktikan bahwa selain facebook dapat saja menjadi sumber kampanye bisnis ia juga dapat menjadi sasaran utama dan sumber konflik yang dapat menimbulkan kondisi krisis bagi humas. Konsumen dapat saja melaporkan ulasan negatif dan berdampak pada reputasi bisnis. Admin facebook tentu harus segera tanggap dalam menanggulangi ulasan dan merespon perkara tersebut, tampilan facebook bisa terlihat pada Gambar 4

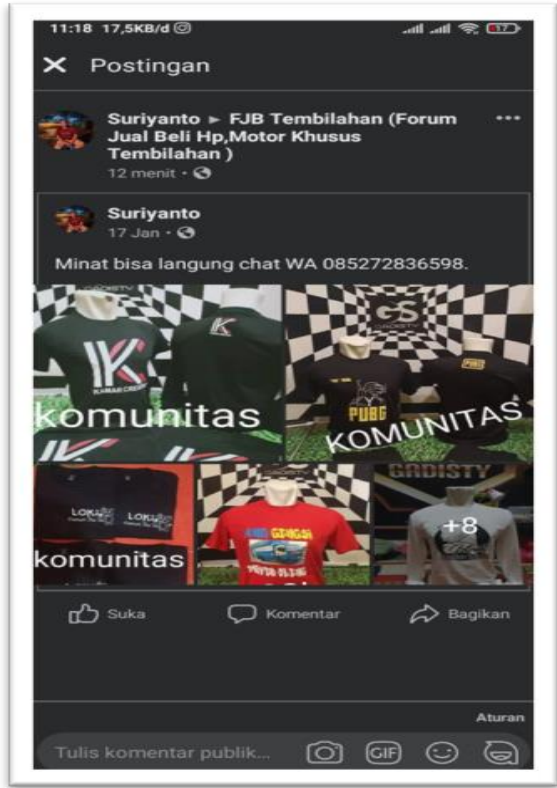

Gambar 4. Cara berkomuniasi Gadisty Sablon Tembilahan

\subsection{Penjualan secara pribadi (Personal Selling)}

Admin facebook biasa melakukan Personal selling seperti dalam kegiatan membalas pertanyaan konsumen pada kolom komentar atau melalui pesan pribadi yang masuk. Selain itu akun facebook personal (pribadi) Gadisty Sablon Tembilahan yang bertindak sebagai pemilik berinteraksi langsung dengan cara mengunggah kiriman layaknya status pribadi facebook masyarakat.

\subsection{Penjualan Langsung (Direct Marketing)}

Bentuk pemasaran dengan cara ini biasa dilakukan oleh admin dengan cara membuat tautan (link) yang mengarahkan publik untuk melakukan pemesanan langsung melalui aplikasi seperti whatsapp, line dan telegram. Facebook fanpage menyediakan fitur tombol pesan sekarang bagi konsumen yang ingin memesan produk setelah melihat foto dan facebook Gadisty Sablon Tembilahan. Melalui akun personal pemilik 
disertakan pula nomor kontak pesan antar. Dengan fasilitas tersebut memberikan kesimpulan bahwa facebook dapat menjadi piranti komunikasi dalam pemasaran langsung atau mendapatkan tanggapan dari pelanggan tertentu dan calon pelanggan, terlihat pada Gambar 5

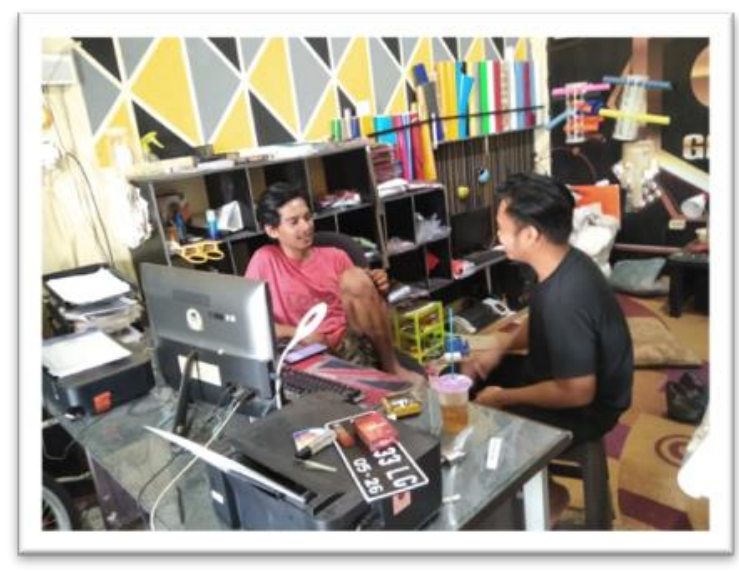

Gambar 5. Direct Marketing Gadisty Sablon Tembilahan

\section{KESIMPULAN DAN SARAN}

Sosial media facebook berperan penting pada aspek riset, perencanaan, pelaksanaan dan evaluasi. Tahap riset facebook memberikan berbagai basis data konten kiriman, interaksi, yang dibutuhkan dalam merumuskan strategi pemasaran yang perlu dieksekusi. Hal ini tidak terlepas dari umpan balik (feedback) yang berperan penting dalam komunikasi atas pesan yang dipublikasikan dan berfungsi untuk melihat kinerja komunikasi pemasaran. Fasilitas lainnya facebook memudahkan tim marketing untuk melihat konten pemasaran dan kinerja tim marketing kompetitor. Hal tersebut dapat digunakan untuk mendapatkan inspirasi konten atau mendapatkan pola strategi baru. Pada tahap perencanaan data facebook menjadi landasan validasi pasar (market validation) dalam rancangan strategi pemasaran. Validasi tersebut akan dijadikan rancangan dalam pengelolaan pelayanan, produk, harga, dan lainnya. Sedangkan untuk tahap pelaksanaan, facebook marketing dapat berperan mengagendakan materi apa yang perlu diunggah pada porsi waktu ideal yang diinginkan oleh tim marketing. Untuk tahap evaluasi, facebook memberikan hasil kinerja strategi pemasaran secara realtime (terkini) yang dapat disaksikan oleh para admin. Evaluasi tersebut juga meliputi pengelolaan kinerja biaya iklan, kompetensi admin mengelola iklan dan ulasan/komentar fans yang turut serta menjadi konsumen.

Strategi dalam pembuatan konten facebook yang perlu diperhatikan adalah adopsi nilai- nilai islami yang dianut oleh perusahaan, mengeksplorasi nilai-nilai positif atau keunggulan dari Gadisty Sablon Tembilahan, minat masyarakat akan isu tertentu dan syarat umum aturan yang diberlakukan oleh facebook agar kampanye iklan dapat maksimal serta tidak mendapatkan hambatan bahkan larangan mengunggah konten dari facebook. Pencapaian strategi tersebut dapat dilihat dari jumlah fans facebook fanpage dalam waktu kurang dari dua tahun menjadi toko baju dan sablon lokal dengan basis fans cukup banyak. Selain itu jumlah pertemanan dari akun personal juga telah mencapai angka banyak. Sekaligus menjadi toko baju dan sablon dengan optimasi facebook marketing populer di kota tembilahan.

Dalam mengeksekusi indikator pemasaran tersebut pihak Gadisty Sablon Tembilahan mengoptimasikan peranan sosial media facebook baik akun fanpage dan personal. Hal yang perlu diperhatikan dalam facebook marketing ialah konten yang atraktif, mengunggah kiriman pada beberapa grup dengan penyesuaian identitasnya, lebih banyak menggunakan metode cover selling/soft selling atau dalam hal ini tidak menjual secara langsung. Hal yang perlu di antisipasi menggunakan metode facebook marketing salah satunya ialah ulasan atau komentar dari masyarakat. Kompetitor dapat meniru kegiatan atau strategi konten yang diformulasikan oleh Gadisty Sablon Tembilahan. Ancaman terakhir ialah ads manager error atau kesalahan dalam memanajerial iklan. Hal ini diakibatkan oleh kandungan materi kiriman gambar iklan yang didominasi teks, atau mengandung konten negatif seperti kekerasan dan pornografi atau dapat pula memiliki kandungan kata/kalimat yang tidak boleh di iklankan. Memperhatikan ancaman diatas dapat disimpulkan bahwa admin dan pembuat konten untuk marketing facebook merupakan pekerjaan yang tidak hanya paham mengenai etika beriklan, namun juga paham hal teknis dalam mengiklan menggunakan facebook, merancang formula strategi marketing, serta dapat menangani krisis yang ditimbulkan oleh facebook.

Efektifitas dan efisiensi menggunakan facebook sebagai media pemasaran online terletak pada kemampuan admin mengalokasikan dana kampanye iklan berbayar dengan memaksimalkan fasilitas targeting khusus dari panel facebook ads manager. Sehingga pesan iklan pemasaran 
dapat terpublikasi dan diketahui oleh publik yang persis sesuai dengan klasifikasi segmentasi konsumen dari Gadisty Sablon Tembilahan. Efisiensi dari segi biaya iklan dibandingkan dengan beriklan menggunakan media konvensional dapat dikatakan lebih murah. Karena kita dapat mengatur pesan akan di kirim kepada publik yang sesuai dengan klasifikasi konsumen, biaya yang dapat diatur sendiri, serta dapat memonitoring laporan dan mengevaluasi kinerja iklan yang disponsori oleh dana iklan secara realtime.

\section{DAFTAR PUSTAKA}

[1]. Z. Muttaqin, "Facebook Marketing Dalam Komunikasi Pemasaran Modern," Teknologi, vol. 1, no. 2, pp. 103-109, 2012, doi: 10.26594/teknologi.v1i2.63.

[2]. M. Rahmatika, "Analisis Faktor-Faktor yang Berpengaruh terhadap Kesadaran Perpajakan Pada Sektor Usaha Kecil Menengah (UKM)," 2010, [Online]. Available:

https://repository.uinjkt.ac.id/dspace/h andle/123456789/867.

[3]. N. H. H. Marismiati Cahyo Prianto, "Pemanfaatan Photo Product Dan Facebook Marketing Untuk Meningkatkan Omset Penjualan UMKM Parongpong," Semin. Nas. Has. PKM LPM Univ. Pas., pp. 128-135, 2018, [Online]. Available: http://proceedings.conference.unpas.ac .id/index.php/pkm/article/view/343.

[4]. M. Rama, "Faktor-Faktor yang Mempengaruhi Kepatuhan Wajib Pajak Usaha Mikro Kecil dan Menengah (UMKM) dalam Membayar Pajak sesuai PP No.23 Tahun 2018 pada UMKM Kabupaten Indragiri Hilir (Inhil)," J. Chem. Inf. Model., vol. 53, no. 9, pp. 1689-1699, 2019, [Online]. Available: http://repository.uinsuska.ac.id/25650/3/GABUNGAN.pdf.

[5]. T. Pradiani, "Pengaruh Sistem Pemasaran Digital Marketing Terhadap Peningkatan Volume Penjualan Hasil Industri Rumahan," J. Ilm. Bisnis dan Ekon. Asia, vol. 11, no. 2, pp. 46-53, 2018, doi: 10.32812/jibeka.v11i2.45.

[6]. W. Siska Aprilia Fauzi, "Sistem Informasi Penjualan Produk Berbasis Web Pada Chanel Distro Pringsewu," J. TAM (Technology Accept. Model., vol. 4, no. 0, pp. 41-47, 2017, [Online]. Available:

http://ojs.stmikpringsewu.ac.id/index.p hp/JurnalTam/article/view/36/36.

[7]. A. Susanto, C. A. Sari, D. R. I. Moses,
E. H. Rachmawanto, and I. U. W. Mulyono, "Implementasi Facebook Marketplace untuk Produk UMKM sebagai Upaya Peningkatan Pemasaran dan Penjualan Online," Abdimasku J. Pengabdi. Masy., vol. 3, no. 1, pp. 4251, 2020, doi: 10.33633/ja.v3i1.64.

[8]. P. Riau, "Wikipedia Indragiri Hilir," Wikipedia, 2019, [Online]. Available: https://journal.unhas.ac.id/index.php/k areba/article/download/6907/3819/183 13. 